\title{
Editorial: Treatment with urokinase
}

This month sees the publication of another article concerning the use of urokinase in the treatment of vitreous haemorrhage and brings the number of reported cases to just under 100 . The use of this fibrinolytic enzyme has given encouraging results in some hands (Forrester and Williamson, 1974) (and in this report) and disappointing results in others (Cleary et al., 1974; Holmes Sellors et al., 1974). Both require an explanation.

The fate of blood in the vitreous is poorly understood, particularly at a pathological level. It is a common observation that bleeding during cataract extraction often gives rise to a shiny pink clot on the vitreous face which resolves within a few weeks. Subhyaloid or preretinal blood remains liquid and can be seen moving over the retinal surface when the patient changes position. However, the fate of blood within the vitreous gel is not known; the natural history of spontaneous clearance is enormously variable. In some cases the vitreous appears to be full of a suspension of red cells, while in others membranes develop. Examination of vitreous aspirate and a post-mortem study of this series does not throw much light on the matter. It is of interest that fibrin has not been detected, and thus the use of a fibrinolytic enzyme is questionable on a theoretical basis. If the enzyme does not work in that way it may have some other action. Likewise, it is difficult to understand how the enzyme could act on intravitreal membranes. However, these questions may be resolved by experimental work which continues in Glasgow (Forrester et al., 1976).

What factors separate the successful from the unsuccessful group? Patient selection seems to be similar in all groups, with a high incidence of diabetic patients and a remainder including cases of hypertension, retinal vascular accident, and excessive anticoagulant.

In some of the earlier reports large amounts of vitreous were aspirated (up to $1.5 \mathrm{ml}$ ) and the urokinase was dissolved in a corresponding volume of water (Dugmore and Raichand, 1973). However, this element of vitreous 'exchange' was not present in the Glasgow reports nor in the current paper. The enzyme was dissolved in $0.3 \mathrm{ml}$ or less and the resulting increase in intraocular pressure balanced by paracentesis. The enzyme is extremely expensive, and this may have led some workers to use inadequate amounts. Most series have reported the use of between 5000 and 25000 Ploug units. It is of interest that the successful groups have mainly used doses in the upper part of this range, and this point deserves further study.

If urokinase can be shown to be of value its use has many advantages. It is easy to inject, and the hospital and inpatient costs are low, though the enzyme itself is expensive. The complications are minor. A transient and non-infective hypopyon is common and in itself requires an explanation; transient glaucoma has been noted, and a moderate incidence of cataract has occurred in this study. Retinal detachment has been found after treatment but was probably present before it; in this regard ultrasound investigations should forewarn the surgeon before treatment is begun. In comparison vitrectomy with one of the many devices on the market is expensive as regards both equipment and hospital costs, and the complications of such surgery are considerable. This is not to detract from the benefit and ever increasing use of these instruments, but ophthalmologists would do well to keep an open mind about simpler methods of clearing vitreous haemorrhage if they can be shown to be of value.

\section{References}

Cleary, P. E., Davies, E. W. G., Shilling, J. S., and Hamilton, A. M. (1974). Intravitreal urokinase in the treatment of vitreous haemorrhage. Transactions of the Ophthalmological Societies of the United Kingdom, 94, 587-590.

Dugmore, W. M., and Raichand, M. (1973). Intravitreal urokinase the treatment of vitreous haemorrhage. American Journal of Ophthalmology, 75, 779-781.

Forrester, J. V., Edgar, W., Prentice, C. R. M., Forbes, C. D., and Williamson, J. (1976). Intravitreal fibrinolysis in experimental vitreous haemorrhage. Experimental Eye Research, 22, 181-188.

Forrester, J. V., and Williamson, J. (1974). Lytic therapy in vitreous haemorrhage. Transactions of the Ophthalmological Societies of the United Kingdom, 94, 583-586.

Holmes Sellors, P. J., Kanski, J. J., and Watson, D. M. (1974). Intravitreal urokinase in the management of vitreous haemorrhage. Transactions of the Ophthalmological Societies of the United Kingdom, 94, 591-596. 